\title{
An Update on the Use of Peer Tutoring and Students with Emotional and Behavioural Disorders
}

\author{
Vicky G. Spencer \\ George Mason University \\ Cynthia G. Simpson and Tonia L. Oatis \\ Sam Houston State University
}

\begin{abstract}
This article presents an update of the research on the use of peer tutoring and students with emotional and behavioural disorders (EBD). Nine studies from 2001 to 2007 were identified in which students with EBD served as tutors and/or tutees to teach their peers academic and social behaviours. Five of these studies included elementary students, two included middle school students, and two included high school students. Only one study (i.e., Tournaki \& Criscitiello, 2003) was implemented in the general education classroom. Peer tutoring continues to be implemented across levels of schooling with the majority of research being conducted at the elementary level in reading with continued secondary interests on the effects of behavioural issues and social skills. Clearly, there is still a need for this intervention to be validated in the middle and secondary classrooms, but specifically, with students with EBD in the general education setting.
\end{abstract}

The relationship between low academic achievement and problem behaviour has been noted in the literature for many years (e.g., Coutinho, 1986; Hinshaw, 1992; Scruggs, Mastropieri, Veit, \& Osguthorpe, 1986; Spencer, Scruggs, \& Mastropieri, 2003). Unfortunately, this relationship often has a negative short- and long-term impact on students' future outcomes (Trout, Nordness, Pierce, \& Epstein, 2003). Academic underachievement is one of the key conditions of emotional and behavioural disorders (EBD), and research has generally led to the conclusion that children and adolescents with EBD often function a year or more below grade level (Kauffman, 2001). One way to address the problem of academic underachievement is to provide effective intervention strategies that can increase academic performance in the classroom.

Peer tutoring is a research-based strategy that continues to show its efficacy with students with EBD. The research of students with EBD serving as tutors and/or tutees to teach their peers a variety of academic and social skills spans well over 30 years (e.g., Greenwood, Delqua- 
dri, \& Hall, 1989; Mathes \& Fuchs, 1993; Scruggs, Mastropieri, \& Richter, 1985; Spencer et al., 2003). Increasing a student's time on task and level of academic engagement, immediate feedback on academic performance, and the potential to include varying ability levels within the classroom are some of the benefits that are supported by peer tutoring research. Therefore, it is not surprising that the research continues to expand in this area.

In 2006, Spencer completed an extensive literature review which examined the use of peer tutoring and students with EBD. Spencer examined 38 studies from 1972 to 2001 and reported an overall effect size of .72 with a range of -.08 to 2.73 . Thus, the effect size for peer tutoring was over one-half of a standard deviation, which is generally considered educationally significant. However, it should be noted that only 13 studies provided enough information to calculate an effect size, which is certainly a limitation of much of the research involving this population of students.

Findings also revealed that students with EBD were successful in serving as both tutors and tutees in reading, writing, and math classes and that research in the area of social studies, although promising, was limited (e.g., Maheady, Harper, \& Sacca, 1988; Maheady, Sacca, \& Harper, 1988; Mastropieri, Scruggs, Spencer, \& Fontana, 2003; Spencer et al., 2003). Based on these findings, this is a strategy that continues to be expanded upon in the field of research. Therefore, the purpose of this updated review was to examine additional studies that were implemented within the last 6 years (those studies not included in the Spencer, 2006, published review). We specifically wanted to know if the use of peer tutoring with students with EBD has expanded into any other academic or social areas, grade levels, or settings. Further, can an effect size be calculated to compare with the 2006 review? This synthesis should provide researchers with some direction on the future use of this effective strategy.

\section{Literature Search Procedures}

Computer assisted searches for relevant literature were conducted in databases such as the Educational Resources Information Center (ERIC) and PsycINFO. Recent issues of all major special education journals were examined for relevant articles. These procedures resulted in the identification of nine new research studies from 2001 to 2007 that included students with EBD as tutors and tutees.

\section{Overall Characteristics of the Data Set}

\section{Criteria for Inclusion}

Studies were included in this synthesis if the primary purpose of the study was to examine the efficacy of same-age or cross-age peer tutoring involving school-age students with EBD as tutors and/or tutees. In addition, the review included peer tutoring interventions that occurred in school settings - public or private - and could be either quantitative or qualitative. Appendix A summarizes each study's characteristics. 


\section{Intervention Descriptions}

In these peer tutoring investigations, two of the studies (i.e., Mastropieri et al., 2003; Spencer et al., 2003) employed experimental-control group designs while seven of the studies employed single subject methodology. The settings for each of these studies varied widely. Four studies were implemented in self-contained schools (i.e., Barton-Arwood, Wehby, \& Falk, 2005; Bowman-Perrott, Greenwood, \& Tapia, 2007; Spencer et al., 2003; Wehby, Falk, BartonArwood, Lane, \& Cooley, 2003), three were conducted in self-contained classrooms (i.e., Falk \& Wehby, 2001; Mastropieri et al., 2003; Sutherland \& Snyder, 2007), and one was conducted in a resource classroom (i.e., Staubitz, Cartledge, \& Yurick, 2005). Only one study was implemented in the general education classroom (i.e., Tournaki \& Criscitiello, 2003). Additionally, these studies included five at the elementary level, two at the middle school level, and two at the high school level.

\section{Tutoring Configurations}

Although peer tutoring can involve one of two basic configurations-same-age peer tutoring or cross-age peer tutoring - it appears that all nine of these studies used same-age peer tutoring. Bowman-Perrott et al. (2007) may have used some cross-age peer tutoring; however, there is not enough information to make that determination. Peer tutoring typically involves pairing students of similar age and ability levels to work together - although there may be some variation in the roles of the students. For example, some peer tutoring studies (e.g., Falk \& Wehby, 2001; Spencer et al., 2003; Sutherland \& Snyder, 2007; Tournaki \& Criscitiello, 2003) also refer to reciprocal peer tutoring or reverse role tutoring which gives each student the opportunity to serve as the tutor and the tutee. Appendix B provides a description of the studies by level/type of schooling, subject, and tutoring configurations.

\section{Content and Duration of Tutoring Sessions}

Peer tutoring was implemented to address both academic and behavioural issues. Five studies implemented reading interventions; other areas of intervention included two in social studies, one in science, and one in behaviour management. The study involving science (i.e., Bowman-Perrott et al., 2007) also included a second study to investigate the effects on spelling. Tutoring investigations ranged anywhere from 4 weeks (Spencer et al., 2003; Tournaki \& Criscitiello, 2003) to a full school year (Barton-Arwood et al., 2005; Bowman-Perrott et al., 2007) and averaged approximately 26 minutes four times a week.

\section{Outcomes of Peer Tutoring}

\section{Elementary Students with EBD}

Five research studies using a single-subject design that were identified involved elementary-age level students with EBD as tutors and/or tutees. Four studies implemented peer tutoring in the content area of reading (i.e., Barton-Arwood et al., 2005; Falk \& Wehby, 2001; Staubitz et al., 2005; Wehby et al., 2003), while the final study focused on using peer tutoring as part of be- 
haviour management (i.e., Tournaki \& Criscitiello, 2003). All four of these studies used sameage peers to implement peer tutoring, although Falk and Wehby (2001) and Wehby et al. (2003) included a reciprocal component. The first three studies also used Peer-Assisted Learning Strategies (PALS; Fuchs et al., 2001) as part of their reading intervention. In the Barton-Arwood et al. (2005) study, six third grade students with EBD attending a self-contained public school were selected for participation in the study. They were paired together and tutored each other. The reading intervention consisted of the Horizons Fast Track A-B reading program (Englemann, Englemann, \& Davis, 1997) and PALS. In addition, data were collected on four student behaviours: engagement, non-engagement, negative talk, and aggression. Results indicated moderate improvements in basic reading skills, but limited and questionable transfer to reading fluency. Furthermore, results were mixed and inconclusive for demonstrating the impact of peer tutoring on the social behaviours.

Falk and Wehby (2001) used Kindergarten Peer-Assisted Learning Strategies (K-PAL) with six kindergarten students with EBD in a self-contained classroom to investigate the effectiveness of increasing beginning reading skills. The students were paired together for the PALS component of the study, which included sound play and decoding. Results of this investigation indicated that PALS was effective in increasing student performance on measures of letter-sound identification and blending; however, performance on blending probes was inconsistent.

The third study using PALS as part of the reading intervention (i.e., Wehby et al., 2003) examined the effectiveness of combining a modified version of the Open Court Reading curriculum (Adams et al., 2000) with PALS for eight kindergarten and first grade students-five students with EBD as the primary or secondary label and three with other disabilities. The two components were implemented at separate times in the school day, but the PALS program was designed to supplement the Open Court Reading curriculum. The program consisted of a variety of activities that focused on decoding and fluency skills for beginning readers. In addition, data were collected for attending to task and inappropriate behaviour. Results showed moderate gains in the areas of nonsense word fluency, sound naming, blending, and segmenting. The authors noted that these findings are similar to those reported in the Falk and Wehby (2001) study. Further, there were no gains in observed target behaviours.

The final study that examined the effects of peer tutoring on reading also used a component of PALS referred to as repeated reading. Staubitz et al. (2005) evaluated the effects of repeated reading on the oral reading fluency and comprehension skills of six fourth and fifth grade students with or at-risk for EBD. All students received academic instruction in resource classrooms and were paired together for this intervention. During the intervention, one student read to his or her partner while the other student followed along and corrected miscues using a scripted correction procedure. Then, each student read the passage individually to the experimenter. Although there was some variation in performance across students, results showed a group mean gain of 8 months improvement in passage comprehension and group gains of 3 months on letter-word identification and reading fluency. Qualitative data from a consumer satisfaction questionnaire from students, teachers, and parents were positive towards the use of the program.

The last of the five studies identified at the elementary level (i.e., Tournaki \& Criscitiello, 2003) used role reversal peer tutoring to examine its effectiveness on improving classroom behaviour in the general education classroom. Five elementary students with EBD who were functioning academically at grade level served as the tutor to five general education students who were functioning academically below grade level. Although the primary focus was behaviour, the tutoring sessions occurred during writing lessons. Data were collected on pushing, 
hitting, cursing, screaming, interrupting others to talk, and out-of-seat behaviour. All five tutors exhibited a reduction in both frequency and duration of the target behaviours, while the tutees' writing scores showed improvements from pretest to posttest.

As is evident with these five studies, peer tutoring continues to be an intervention that can produce positive results in the area of reading for students with EBD. However, findings regarding the improvement of social behaviours are still questionable. While Wehby et al. (2003) and Falk and Wehby (2001) did not find a significant decrease in problem behaviours, Tournaki and Criscitiello (2003) reported "dramatic reductions of target behaviours by the tutors" (p. 24). It should be noted that the tutors in this study were the students with EBD; thus, the need for further research is clear. In addition, the number of participants was low, thus limiting generalization; follow-up was not included in any of these studies.

\section{Middle School Students with EBD}

Two research studies examined the use of reciprocal peer tutoring at the middle school level. In 2003, Spencer and colleagues investigated the use of integrated explicit strategy instruction in social studies classes using a peer tutoring format. Thirty students attending social studies classes in a middle school for students with EBD studied social studies content in a crossover design, in which all students received each of two instructional conditions. In one treatment condition, students served as peer tutors using a paragraph summary strategy. In the other condition, students received traditional instruction. After 4 weeks of tutoring, results indicated that students scored higher on content tests and on-task behaviour while in the tutoring condition. Qualitative data from a Student Satisfaction Survey suggested that students enjoyed peer tutoring relative to traditional instruction and reported that they would like to use it in other classes. Teachers agreed that peer tutoring and strategy instruction had exerted a facilitative effect on student performance.

In 2007, Sutherland and Snyder extended the Spencer et al. (2003) study by examining the effects of reciprocal peer tutoring and self-graphing of reading data on the disruptive behaviour, active responding, and reading fluency of four middle school students with EBD in a selfcontained classroom. During the peer tutoring sessions, the students read children's literature that had been selected by the teacher while following the PALS procedures (i.e., partner reading, paragraph shrinking, prediction relay). The students were taught to self-graph their words read correctly and their errors as well as their Curriculum Based Measurement data. Disruptive behaviour was recorded by an observer using a frequency count. Results showed a decrease in the students' disruptive behaviours and an increase in active responding. Each student also made progress on words read correctly per minute. Qualitative data from the Student Satisfaction Survey was consistent with the Spencer et al. (2003) findings in that the students clearly preferred the intervention to their typical instruction. Unfortunately, follow-up observations indicated that the intervention was not being used in the classroom.

\section{High School Students with EBD}

The last two studies included in the review involved high school students with EBD serving as tutors and/or tutees using classwide peer tutoring. In a two-part study, Bowman-Perrott et al. (2007) examined the effectiveness of classwide peer tutoring in Study 1, and classwide peer 
tutoring with classwide self-management in Study 2 as interventions for students with EBD in alternative school settings. On-task behaviour observations were also taken throughout the course of both studies. It should be noted that these studies involved a total of 19 fifth-twelfth grade students with EBD, but the reviewer made the decision to list it as a high-school study because the author refers to it as a secondary study.

In the first study, the academic focus was biology. The high school students were placed in pairs and worked together using a reciprocal peer tutoring format. Points were given to tutors and tutees for appropriate tutoring behaviours and team points were given at the end of each class. Results revealed a moderate effect from pre- to post-test, but there was a definite increase in on-task behaviour. In the second study, the academic focus was spelling, and it was implemented in a middle school spelling class. The same peer tutoring format was used, but only individual contingencies were used. Students earned citizenship points from their peer tutors for working well in peer tutoring. This was the classwide self-management component. Students made more improvements in accuracy of responses than students in the first study. The classwide self-management component provided students with a systematic way of monitoring their behaviour during instruction. Again, students were more on-task and engaged in academic tasks. Satisfaction surveys indicated that the majority of students liked classwide peer tutoring and would like to continue using it in future classes.

In the final study, Mastropieri et al. (2003) used an experimental design to make comparisons between peer tutoring and teacher-directed guided notes in a world history class for 16 tenth grade students with mild disabilities; one student was identified as having EBD. In the peer tutoring condition, students were paired together and served as both the tutor and the tutee in learning the world history information. In addition, the students worked with their partner to complete a summarization strategy worksheet that required them to answer comprehension questions. In the guided notes condition, the teacher directed all aspects of the implementation which included a daily review, presentation of new information, and guided and independent practice. Next, the students participated in oral reading one at a time and the teacher used questioning strategies to activate prior knowledge, recall, and comprehension. After reading the text, students independently completed guided-study notes. Findings revealed that students who participated in peer tutoring significantly outperformed those who participated in the guided notes condition on content area tests. Fluency measures did not produce measurable gains, but students in the peer tutoring condition performed significantly better at using a reading comprehension summarization strategy independently.

Findings of these four studies that included middle and high school students with EBD produced some positive academic effects and increased on-task behaviours in content-area classes. Consistent with findings at the elementary level, students' comments were positive regarding the use of peer tutoring as an intervention strategy.

\section{Limitations}

Several important limitations must be noted. First, search procedures included two electronic databases and a review of all reference lists of obtained articles; it is possible that with specific descriptors used, there were some articles that were unintentionally overlooked. Second, only two studies provided enough information to calculate effect sizes. Last, with seven of nine studies using single subject designs a small number of subjects were included; therefore, generalization is limited. 


\section{Conclusions and Implications for Future Research}

A review of nine research studies that were implemented from 2001 to 2007 indicates that peer tutoring continues to be an effective instructional strategy for elementary, middle, and high school students with EBD. Five of the peer tutoring studies included elementary students, two studies included middle school students, and two studies included high school students. Only one study (Tournaki \& Criscitiello, 2003) was implemented in the general education classroom. Clearly, there is still a continued need for this intervention to be validated in the middle and secondary classrooms, but even more important is the need for this intervention to be examined with this population of students in the general education classroom setting. This is especially important since many students with EBD are now receiving their instruction in the general education classroom (Kauffman, 2001).

In an examination of whether or not the use of peer tutoring with students with EBD has been expanded into any other academic or social areas, grade levels, or settings, the strategy continues to be implemented across levels of schooling with the majority of research being conducted at the elementary level in reading. In addition, an examination of social behaviours continues to be a part of the dependent measures used to see if the use of peer tutoring can reduce behavioural issues and improve social skills at the elementary (Barton-Arwood et al., 2005; Tournaki \& Criscitiello, 2003) and the middle school level (Sutherland \& Snyder, 2007).

While two studies from the 2006 review explored these issues at the elementary level (i.e., Scruggs et al., 1986; Shisler, Top, \& Osguthorpe, 1986) and two studies at the middle school level (i.e., Blake, Wang, Cartledge, \& Gardner, 2000; Lazerson, 1980), all of these studies have yielded promising results. It is important to note that there is variation in the specific behaviours and social skills that are being measured within each of these studies; however, there is a great deal of overlap. Thus, it seems plausible that research should continue along this line and possibly expand into the high school level, since to date behavioural and social issues have not been explored at the high school level.

In response to our questions regarding effect sizes, only two studies provided enough information to calculate effect sizes, which was one of the purposes of updating the review of the literature. Mastropieri et al. (2003) reported an average in excess of 1.5 standard deviation units while Spencer et al. (2003) reported an average of .72 standard deviation units. The overall effect size for the 13 studies in the Spencer (2006) review provided an overall effect size of .72. Although, these two more recent studies provide support for the previous findings of the Spencer review, comparisons cannot be made with such a small number reporting.

Consistent with previous literature, peer tutoring continues to be a strategy that students with EBD and teachers responded to favourably, while some social and behavioural benefits have also been noted. As we continue to examine intervention strategies for students with EBD it is imperative that we provide the results of these reviews to the classroom teachers who are working with these students on a daily basis. 


\section{References}

Adams, M. J., Bereiter, C., Carruthers, I., Case, R., Hirshberg, J., McKeough, A., et al. (2000). Open court reading. Columbus, $\mathrm{OH}$ : $\mathrm{SRA} / \mathrm{McGraw}-\mathrm{Hill}$.

Barton-Arwood, S., Wehby, J., \& Falk, K. (2005). Reading instruction for elementary-age students with emotional and behavioral disorders: Academic and behavioral outcomes. Exceptional Children, 72, 7-27.

Blake, C., Wang, W., Cartledge, G., \& Gardner, R. (2000). Middle school students with serious emotional disturbances serve as social skills trainers and reinforcers for peers with SED. Behavioral Disorders, 25, 280-298.

Bowman-Perrott, L. J., Greenwood, C. R., \& Tapia, Y. (2007). The efficacy of CWPT used in secondary alternative school classrooms with small teacher/pupil ratios and students with emotional and behavioral disorders. Education and Treatment of Children, 39, 65-87.

Coutinho, M. J. (1986). Reading achievement of students identified as behaviorally disordered at the secondary level. Behavioral Disorders, 11, 200-207.

Englemann, S., Englemann, O., \& Davis, K. L. S. (1997). Horizons. Columbus, OH: SRA/McGraw Hill.

Falk, K. B., \& Wehby, J. H. (2001). The effects of peer-assisted learning strategies on the beginning reading skills of young children with emotional or behavioral disorders. Behavioral Disorders, 26, 344-359.

Fuchs, D., Fuchs, L. S., Thompson, A., Svenson, E., Yen, L., Otaiba, S. A., et al. (2001). Peer-assisted learning strategies in reading: Extensions for kindergarten, first grade, and high school. Remedial and Special Education, 22, 15-21.

Greenwood, C. R., Delquadri, J. C., \& Hall, R. V. (1989). Longitudinal effects of classwide peer tutoring. Journal of Educational Psychology, 81, 371-383.

Hinshaw, S. P. (1992). Externalizing behavior problems and academic underachievement in childhood and adolescence: Causal relationships and underlying mechanisms. Psychological Bulletin, 111, 127-155.

Kauffman, J. M. (2001). Characteristics of emotional and behavioral disorders in children and youth (7th ed.). Upper Saddle River, NJ: Merrill/Prentice Hall.

Lazerson, D. B. (1980). I must be good if I can teach! - Peer tutoring with aggressive and withdrawn children. Journal of Learning Disabilities, 13, 43-48.

Maheady, L., Harper, G. F., \& Sacca, M. K. (1988). A classwide peer tutoring system in a secondary resource room program for the mildly handicapped. Journal of Research and Development in Education, 21(3), 76-83.

Maheady, L., Sacca, M. K., \& Harper, G. F. (1988). Classwide peer tutoring with mildly handicapped high school students. Exceptional Children, 55, 52-59.

Mastropieri, M. A., Scruggs, T. E., Spencer, V. G., \& Fontana, J. (2003). Improving outcomes in high school world history: The relative effects of peer tutoring vs. guided notes. Learning Disabilities Research \& Practice, 18, 52-65.

Mathes, P. G., \& Fuchs, L. S. (1993). Peer-mediated reading instruction in special education resource rooms. Learning Disabilities Research \& Practice, 8, 233-243.

Scruggs, T. E., Mastropieri, M. A., \& Richter, L. (1985). Peer tutoring with behaviorally disordered students: Social and academic benefits. Behavioral Disorders, 10, 283-294.

Scruggs, T. E., Mastropieri, M. A., Veit, D. T., \& Osguthorpe, R. T. (1986). Behaviorally disordered students as tutors: Effects on social behavior. Behavioral Disorders, 12, 36-44.

Shisler, L., Top, B. L., \& Osguthorpe, R. T. (1986). Behaviorally disordered students as reverse-role tutors: Increasing social group acceptance and reading skills. BC Journal of Special Education, 10, 101-119.

Spencer, V. G. (2006). Peer tutoring and students with emotional or behavioral disorders: A review of the literature. Behavioral Disorders, 32, 204-222. 
Spencer, V. G., Scruggs, T. E., \& Mastropieri, M. A. (2003). Content area learning and students with emotional or behavioral disorders: A comparison of strategies. Behavioral Disorders, 28, 77-93.

Staubitz, J. E., Cartledge, G., \& Yurick, A. L. (2005). Repeated reading for students with emotional or behavioral disorders: Peer- and trainer-mediated instruction. Behavioral Disorders, 31, 51-64.

Sutherland, K., \& Snyder, A. (2007). Effects of reciprocal peer tutoring and self-graphing on reading fluency and classroom behavior of middle school students with emotional or behavioral disorders. Journal of Emotional and Behavioral Disorders, 15, 103-118.

Tournaki, N., \& Criscitiello, E. (2003). Using peer tutoring as a successful part of behavioral management. Teaching Exceptional Children, 36(2), 22-29.

Trout, A. L., Nordness, P. D., Pierce, C. D., \& Epstein, M. H. (2003). Research on the academic status of children with emotional and behavioral disorders: A review of the literature from 1961 to 2000 . Journal of Emotional and Behavioral Disorders, 11, 198-210.

Wehby, J. H., Falk, K. B., Barton-Arwood, S., Lane, K. L., \& Cooley, C. (2003). The impact of comprehensive reading instruction on the academic and social behavior of students with emotional and behavioral disorders. Journal of Positive Emotional and Behavioral Disorders, 11(4), 225-238.

\section{Authors' Note}

Correspondence concerning this article should be addressed to Vicky G. Spencer, Ph.D., Assistant Professor, Department of Special Education, Assistant Director of Helen A. Kellar Institute for Human Disabilities, George Mason University, 4400 University Dr., MS 1 F2, Fairfax, VA, 22030. Email: vspencer@gmu.edu. 
Appendix A

Findings from Empirical Studies Involving Students with Emotional Disorders and Peer Tutoring

\begin{tabular}{|c|c|c|c|c|c|}
\hline Study Authors & Design & Tutors/tutees & $\begin{array}{l}\text { Duration of } \\
\text { intervention }\end{array}$ & Depended measures & Reported findings \\
\hline $\begin{array}{l}\text { Barton-Arwood et } \\
\text { al. (2005) }\end{array}$ & $\begin{array}{l}\text { Multiple baseline } \\
\text { across subjects }\end{array}$ & $\begin{array}{l}\text { Same-age tutoring } \\
\text { Tutors: } N=6 \text {, } \\
\text { Grade } 3, \mathrm{ED} \text {, } \\
\text { LD,OHI, SI }\end{array}$ & $\begin{array}{l}\text { Horizons Fast Track: } \\
30 \mathrm{~min} / \mathrm{day}, \\
4 \text { days/week } \\
\text { PALS: } 30 \mathrm{~min} / \text { day, } \\
3 \text { days/week } \\
\text { for } 1 \text { academic year }\end{array}$ & $\begin{array}{l}\text { Letter identification } \\
\text { Word identification } \\
\text { Word attack }\end{array}$ & $\begin{array}{l}\text { Moderate improvements in basic } \\
\text { reading skills with limited transfer } \\
\text { to reading fluency }\end{array}$ \\
\hline $\begin{array}{l}\text { Bowman-Perrott } \\
\text { et al. (2007) }\end{array}$ & $\begin{array}{l}\text { Single subject } \\
\text { design }\end{array}$ & $\begin{array}{l}\text { Study 1: may be } \\
\text { cross-age (unclear) } \\
N=19 \text {, grades } 5-12 \\
\text { w/ EBD } \\
\text { Study } 2 \text { : same-age } \\
\text { tutoring }\end{array}$ & $\begin{array}{l}\text { Study 1: CWPT } 30 \\
\text { min., } 3 \text { times/week for } \\
2 \text { semesters } \\
\text { Study 2: CWPT } 30 \\
\text { min., } 3 \text { times/week for } \\
1 \text { semester and } \\
\text { CWSM }\end{array}$ & $\begin{array}{l}\text { Pre- and Post-test } \\
\text { in Biology and Spelling } \\
\text { On-task observations } \\
\text { Student satisfaction survey }\end{array}$ & $\begin{array}{l}\text { Academic outcomes: } \\
\text { Study } 1 \text { had moderate effects while } \\
\text { Study } 2 \text { results were more promis- } \\
\text { ing when CWPT was paired with } \\
\text { CWSM } \\
\text { On-task behaviour increased in } \\
\text { both studies }\end{array}$ \\
\hline $\begin{array}{l}\text { Falk \& Wehby } \\
(2001)\end{array}$ & $\begin{array}{l}\text { Multiple baseline } \\
\text { across tutoring } \\
\text { pairs }\end{array}$ & $\begin{array}{l}\text { Same-age } \\
\text { reciprocal tutoring } \\
N=6 \text {, kindergarten } \\
\text { students with SI, } \\
\text { ED, or } \mathrm{OHI}\end{array}$ & $\begin{array}{l}\text { Intervention lasted } 11 \\
\text { weeks; } 3 \text { times/week } \\
\text { for } 20-25 \mathrm{~min}\end{array}$ & $\begin{array}{l}\text { Letter naming probe } \\
\text { Letter sound probe } \\
\text { Segmentation probe } \\
\text { Blending probe }\end{array}$ & $\begin{array}{l}\text { Tutoring component of K-PAL was } \\
\text { effective in increasing student per- } \\
\text { formance on measures of letter- } \\
\text { sound identification and blending } \\
\text { Blending skills also increased in } \\
5 / 6 \text { students, only } 1 / 6 \text { improved in } \\
\text { segmentation }\end{array}$ \\
\hline $\begin{array}{l}\text { Mastropieri et al. } \\
(2003)\end{array}$ & Exp. vs. Control & $\begin{array}{l}\text { Same-age } \\
\text { reciprocal tutoring } \\
N=16, \text { Grade } 10, \\
\text { (1) ED/LD, (1) MMR, } \\
\text { (14) LD }\end{array}$ & $\begin{array}{l}\text { Intervention lasted } 8 \\
\text { weeks; } 2 \text { or } 3 \\
\text { times/week for } 85 \text { min } \\
\text { (block scheduling) }\end{array}$ & $\begin{array}{l}\text { Pre-post World History tests } \\
\text { Oral reading fluency } \\
\text { Student satisfaction survey }\end{array}$ & $\begin{array}{l}\text { Students in peer tutoring class } \\
\text { made significant gains over the } \\
\text { students in traditional class } \\
\text { Positive teacher \& student attitudes } \\
\text { regarding peer tutoring } \\
\text { No significant difference on reading } \\
\text { fluency }\end{array}$ \\
\hline
\end{tabular}


Findings from Empirical Studies Involving Students with Emotional Disorders and Peer Tutoring (Cont'd)

\begin{tabular}{|c|c|c|c|c|c|}
\hline Study Authors & Design & Tutors/tutees & $\begin{array}{l}\text { Duration of interven- } \\
\text { tion }\end{array}$ & Depended measures & Reported findings \\
\hline $\begin{array}{l}\text { Spencer et al. } \\
(2003)\end{array}$ & Exp. vs. Control & $\begin{array}{l}\text { Same-age } \\
\text { reciprocal tutoring, } \\
N=30 \text {, grades } 7-8 \\
\text { w/EBD }\end{array}$ & $\begin{array}{l}\text { Intervention lasted } 4 \\
\text { weeks, } 35 \mathrm{~min} / \text { day }\end{array}$ & $\begin{array}{l}\text { Pre-post chapter tests } \\
\text { Pre-post summarization } \\
\text { strategy tests } \\
\text { Time on-task } \\
\text { Weekly quizzes } \\
\text { Student satisfaction survey } \\
\text { Teacher interviews }\end{array}$ & $\begin{array}{l}\text { Increase on social studies weekly } \\
\text { quizzes \& chapter tests } \\
\text { Increase of on-task behaviour } \\
\text { Minimal gains on summary strate- } \\
\text { gies } \\
\text { Student surveys \& teacher inter- } \\
\text { views revealed positive attitudes } \\
\text { toward peer tutoring }\end{array}$ \\
\hline $\begin{array}{l}\text { Staubitz et al. } \\
(2005)\end{array}$ & $\begin{array}{l}\text { Multiple baseline } \\
\text { across subjects }\end{array}$ & $\begin{array}{l}\text { Same-age tutoring } \\
N=6, \text { grades } 4-5, \\
\text { w/ or at risk for } \\
\text { ED/EBD }\end{array}$ & $\begin{array}{l}\text { Intervention lasted } \\
1.5-4 \text { months; three } \\
20-\text { min training ses- } \\
\text { sions, and } 10 \text { min } \\
\text { peer-mediated RR }\end{array}$ & $\begin{array}{l}\text { Oral reading rate } \\
\text { Accuracy } \\
\text { Comprehension } \\
\text { Consumer satisfaction } \\
\text { questionnaires }\end{array}$ & $\begin{array}{l}\text { Gains as a group on all } 4 \text { subtests } \\
\text { of the WJ III from pre-testing to } \\
\text { post-testing, although oral reading } \\
\text { fluency and comprehension varied }\end{array}$ \\
\hline $\begin{array}{l}\text { Sutherland \& } \\
\text { Snyder (2007) }\end{array}$ & $\begin{array}{l}\text { Multiple baseline } \\
\text { across subjects }\end{array}$ & $\begin{array}{l}\text { Same-age } \\
\text { reciprocal tutoring } \\
N=4 \text {, middle school } \\
\text { students w/ EBD }\end{array}$ & $\begin{array}{l}\text { Intervention lasted } 20 \\
\mathrm{~min} / \text { day for } 11 \text { weeks }\end{array}$ & $\begin{array}{l}\text { Frequency of disruptive } \\
\text { behavior } \\
\text { Active responding } \\
\text { CBM } \\
\text { Student Satisfaction Survey }\end{array}$ & $\begin{array}{l}\text { Students' disruptive behaviour de- } \\
\text { creased and active responding } \\
\text { increased. Each student made } \\
\text { progress on words read correctly } \\
\text { per minute. }\end{array}$ \\
\hline $\begin{array}{l}\text { Tournaki \& } \\
\text { Criscitiello (2003) }\end{array}$ & Multiple baseline & $\begin{array}{l}\text { Same-age, role- } \\
\text { reverse tutoring } \\
\text { Tutors: } N=5, \\
\text { Grade } 1 \mathrm{w} / \mathrm{EBD} \\
\text { Tutees: } N=5,1^{\text {st }} \\
\text { graders }\end{array}$ & $\begin{array}{l}\text { Intervention lasted } 20 \\
\text { consecutive school } \\
\text { days for } 20 \text { min of the } \\
\text { second and third } \\
\text { school periods. }\end{array}$ & $\begin{array}{l}\text { Frequency and duration of } \\
\text { target behaviors: } \\
\text { pushing; hitting; cursing; } \\
\text { screaming; interrupting oth- } \\
\text { ers to talk; out of seat; } \\
\text { writing skills }\end{array}$ & $\begin{array}{l}\text { Each of the } 5 \text { students exhibited a } \\
\text { reduction in both frequency and } \\
\text { duration of target behaviour }\end{array}$ \\
\hline $\begin{array}{l}\text { Wehby et al. } \\
(2003)\end{array}$ & $\begin{array}{l}\text { Multiple baseline } \\
\text { across groups }\end{array}$ & $\begin{array}{l}\text { Same-age } \\
\text { reciprocal tutoring } \\
N=8 \text {, ranging in } \\
\text { age from } 7-10,6 \\
\text { were identified as } \\
\text { ED, other labels } \\
\text { included LD, MR, } \\
\text { OHI, SPL }\end{array}$ & $\begin{array}{l}\text { Intervention lasted } 45 \\
\text { min/day, } \\
4 \text { days/week for } 7 \\
\text { weeks }\end{array}$ & $\begin{array}{l}\text { Nonsense word fluency } \\
\text { probe } \\
\text { Blending probe } \\
\text { Letter-sound correspon- } \\
\text { dence } \\
\text { Sight word recognition } \\
\text { Behavioural observations }\end{array}$ & $\begin{array}{l}\text { Moderate gains in reading } \\
\text { achievement for individuals in each } \\
\text { of the probes; however, there was } \\
\text { no improvement in standardized } \\
\text { scores, and there was no impact } \\
\text { on observed problem behaviour }\end{array}$ \\
\hline
\end{tabular}




\section{Appendix B}

Studies' Descriptives by Level of Schooling, Subject, and Tutoring Configurations

\begin{tabular}{|c|c|c|c|}
\hline Study Authors & Level/Type of Schooling & Subject & Tutoring Configurations \\
\hline \multirow{2}{*}{$\begin{array}{l}\text { Barton-Arwood, Wehby, \& Falk } \\
\text { (2005) }\end{array}$} & Elementary & Reading & \multirow[t]{2}{*}{ Same-age tutoring } \\
\hline & Self-contained school & Social Behaviours & \\
\hline $\begin{array}{l}\text { Bowman-Perrott, Greenwood, \& } \\
\text { Tapia (2007) }\end{array}$ & $\begin{array}{l}\text { High school; middle school; } \\
\text { alternative school }\end{array}$ & $\begin{array}{l}\text { Science (Study 1) } \\
\text { Spelling (Study 2) }\end{array}$ & $\begin{array}{l}\text { Reciprocal peer } \\
\text { tutoring }\end{array}$ \\
\hline Falk \& Wehby (2001) & $\begin{array}{l}\text { Elementary } \\
\text { Self-contained classroom }\end{array}$ & Reading & $\begin{array}{l}\text { Same-age reciprocal } \\
\text { tutoring }\end{array}$ \\
\hline Mastropieri et al. (2003) & $\begin{array}{l}\text { High School } \\
\text { Self-contained classroom }\end{array}$ & World History & $\begin{array}{l}\text { Same-age reciprocal } \\
\text { tutoring }\end{array}$ \\
\hline Spencer et al. (2003) & $\begin{array}{l}\text { Middle School } \\
\text { Self-contained school }\end{array}$ & Social Studies & $\begin{array}{l}\text { Same-age reciprocal } \\
\text { tutoring }\end{array}$ \\
\hline $\begin{array}{l}\text { Staubitz, Cartledge, \& Yurick } \\
(2005)\end{array}$ & $\begin{array}{l}\text { Elementary } \\
\text { Resource classroom }\end{array}$ & $\begin{array}{l}\text { Reading Fluency } \\
\text { Comprehension }\end{array}$ & Same-age tutoring \\
\hline Sutherland \& Snyder (2007) & $\begin{array}{l}\text { Middle School } \\
\text { Self-contained classroom }\end{array}$ & $\begin{array}{l}\text { Reading Fluency } \\
\text { Disruptive Behaviours }\end{array}$ & $\begin{array}{l}\text { Same-age reciprocal } \\
\text { tutoring }\end{array}$ \\
\hline Tournaki \& Criscitiello (2003) & $\begin{array}{l}\text { Elementary } \\
\text { General education classroom }\end{array}$ & $\begin{array}{l}\text { Target Behaviours } \\
\text { Writing skills }\end{array}$ & $\begin{array}{l}\text { Same-age tutoring, } \\
\text { reverse role }\end{array}$ \\
\hline $\begin{array}{l}\text { Wehby, Falk, Barton-Arwood, } \\
\text { Lane, \& Cooley (2006) }\end{array}$ & $\begin{array}{l}\text { Elementary } \\
\text { Self-contained school }\end{array}$ & Reading & $\begin{array}{l}\text { Same-age reciprocal } \\
\text { tutoring }\end{array}$ \\
\hline
\end{tabular}

Appendix C

Examination of Expansion of Peer Tutoring

\begin{tabular}{lcc}
\hline & $\begin{array}{c}\text { Level of Schooling and Subject } \\
\text { 2006 Review }\end{array}$ & $\begin{array}{c}\text { Level of Schooling and Subject } \\
2008 \text { Review }\end{array}$ \\
& $\left(N=17^{*}\right)$ & $(N=5)$ \\
(studies from 1972-2002) & 0 \\
\hline Elementary & 4 & 1 \\
Academic \& electives & 0 & 0 \\
Behaviour management & $2003-2007)$ \\
Math & 8 & 3 \\
Reading & 0 & 1 \\
Reading/social behaviours & 2 & 0 \\
Social skills/language & $(N=5)$ & $(N=2)$ \\
Middle school & 1 & 0 \\
Math & 0 & 1 \\
Reading \& behaviour & 1 & 0 \\
Social/emotional behaviours & 2 & 0 \\
Social skills & 1 & 1 \\
Social studies & $(N=16)$ & $(N=2)$ \\
High school & 3 & 0 \\
Math & 3 & 0 \\
Math/language arts/social science & 4 & 0 \\
Reading & 0 & 1 \\
Science \& Spelling & 3 & 0 \\
Spelling & 3 & 0 \\
Social studies & 0 & 1 \\
World history & 2 & \\
\hline
\end{tabular}

${ }^{*}$ Total number of studies does not equal 17 because one study included two experiments.

13 Exceptionality Education International, 2009, Vol. 19, No. 1 